Saudi Journal of Medicine

Abbreviated Key Title: Saudi J Med ISSN 2518-3389 (Print) |ISSN 2518-3397 (Online) Scholars Middle East Publishers, Dubai, United Arab Emirates Journal homepage: https://saudijournals.com/sjm

Original Research Article

\title{
Implementation and evaluation of an e-learning system - A Cross- Sectional Study in a Medical College, Pakistan
}

\author{
Saba Iqbal $^{1^{*}}$, Rabia Akram², Sameea Akram ${ }^{3}$, Lamia Yusuf ${ }^{4}$ \\ ${ }^{1}$ Assistant Professor in Pak Red Crescent Medical \& Dental College, Dina Nath, Kasur, Punjab, Pakistan \\ ${ }^{2}$ Assistant Professor in Gynea \& Obst, Shalamar institute of health sciences, Lahore, Pakistan \\ ${ }^{3}$ Assistant Professor in Paediatric Medicine, Nawaz Sharif Medical College, Gujrat, Punjab, Pakistan \\ ${ }^{4}$ Associate professor in Gynea \& Obst, Pak Red Crescent Medical and Dental College, Punjab, Pakistan
}

DOI: $\underline{10.36348 / \mathrm{sjm} .2020 . \mathrm{v} 05 \mathrm{i} 06.005}$

| Received: 03.06.2020 | Accepted: 11.06.2020 | Published: 30.06 .2020

*Corresponding Author: Saba Iqbal

\section{Abstract}

The aim of this study was to investigate the current opinions of undergraduate Medical students at the Pak Red Crescent Medical College of Pakistan in respect to information communication technology (ICT), by implementing e-learning system by mixing different strategies, start the e learning program first time on regular bases and then assess the feedback by MBBS Medical students from the first, second, third, fourth, and fifth year and they were asked to complete a questionnaire presented in a e-docs at the end of the sixth week of the e-learning during the lock down due to covid-19 pandemic. Students give a mix response, they feel difficulty to understand medical education first time online but later on they enjoy the whole learning process especially non clinical subjects and e feedback results shows, and Students do not want e-learning as replacing traditional instructor-based training but as a additional component to it, forming part of a blended-learning strategy. Assessments are quickly assessed and quick respond and less chance of cheating. A major disadvantage of early e-learning system, it only covers the cognation process, skill and attitude component of medical teaching and training is not fully taught and hands on activities are impossible to assess through e-learning.

Keywords: e-learning, Medical education, Coverd19, Distance learning program, Medical College, Medical Students.

Copyright @ 2020: This is an open-access article distributed under the terms of the Creative Commons Attribution license which permits unrestricted use, distribution, and reproduction in any medium for non-commercial use (NonCommercial, or CC-BY-NC) provided the original author and source are credited.

\section{INTRODUCTION}

In past few weeks, it has been drastic changes in life style all over the world, particular in, Pakistan. This began last 6 weeks with a lock down, the closer of school, colleges and universities across the country and now complete lockdown across the whole country. Because of the virus, also known as COVID-19 by the World Health Organization (WHO) [1], close to a millions of students as well as teachers have been forced to remain indoors in 213 countries and territories worldwide [2]. The corona virus will usher us in a new age of home based working and e-learning.

Medical education has many long established pedagogical approaches to learning including face to face lectures, tutorials, small group discussions in classrooms, tutorial rooms, laboratories, wards and in lecture halls, via a teacher-centered model [3]. But recently the rapid involvement of iPads, smart phones, tablets, and e-book readers has personal digital devices in the education systems around the world has been observed [4]. Computerized technological resources have become essential in new era of medical education, particularly for basic sciences teaching or other medical science topics that require the performance of specific tasks [5, 6]. This electronic learning (e-learning) is moving from textbooks in modern electronic format $\mathrm{e}$ books [7]. These resources can effectively help the execution of such tasks and the teaching-learning process itself. For last 10 years, the increased widespread use of e-Textbooks in education has been anticipated because of its flexibility, adaptability, accessibility, availability interactivity, and extensibility [4]. E-learning has always been standard as a basic element to facilitate effective and efficient teaching and learning including the context of basic sciences and in clinical practice [8].

\section{Definition}

According to the Oxford English dictionary " A learning system based on formalized studying at home but with the help of electronic resources on the internet is known as E-learning" [9] and the Medical education is "education related to the practice of being a medical practitioner; either the initial training to become a physician" 3]. Distance learning program conventionally defined as: any educational learning program in which the teacher and students are in 
separated geographically or in time from his or her students; or in which students are separated from other students or educational resources [10].

As desire to continue medical education, we design Distance learning program, e-learning systems based on the principles and prerequisites of teaching and learning theories requires a comprehensive and systematic approach to instructional design procedures [4]. We use mixture of software to communicate between staff and with the students, including Google class room, Zoom, webinar, padlet and moodly. These educational media possess several distinct advantages over traditional didactic models of instruction. This is consistent with the use of modern technology to enhance the educational experiences of learners and educators [8]. An analyzing of the experience of instructional design, implementation and evaluation of an e-learning system is represented in this study.

\section{OBJECTIVE}

To find out the effectiveness of newly established e-learning and assessment system in medical education.

\section{METHODOLOGY}

A systematic approach to implementing e-learning by mixing different strategies to ensure successful implementation of the e-learning agenda:

1. Grounding technology choices in learning theory, curriculum values, and teaching practice

2. Thinking critically about communications needs

3. Engaging students-facilitators to provide support and expertise

4. Providing training and support for faculty and students

5. Provide students guidelines and instructions

6. Engaging faculty and students (by time table)

7. Intentionally engaging students (by assignments and quiz)

8. Considering sustainability throughout the implementation process

9. Integrating continuous evaluation (by forms) as part of the feedback process.

There was much intentionality in opt technologies to align with and enhance educational approaches.

\section{Steps of establishment of e learning program:}

1. Identify the different moods of e learning.

2. Trained the facilitators by workshop and hands on training.
3. Make different classrooms on Google and meeting ids on zoom.

4. Approach the students and facilitate them to make a Google mailing id address.

5. Send the classroom codes and meeting ids to the students

6. Making the e-learning time table.

7. Communicate the students that the classroom attendance which is based on submission of assignments and Quiz on given time.

It is a Prospective and cross-sectional study. The questionnaire was designed to obtain information on the student's e learning program. Questionnaire based study was conducted among 390 students of first, 2nd, 3rd, 4th and final year undergraduate MBBS, of Pak Red Crescent medical college at Dina Nath in March-April 2020. All the ethical guidelines were followed. Participation in this study was voluntary.

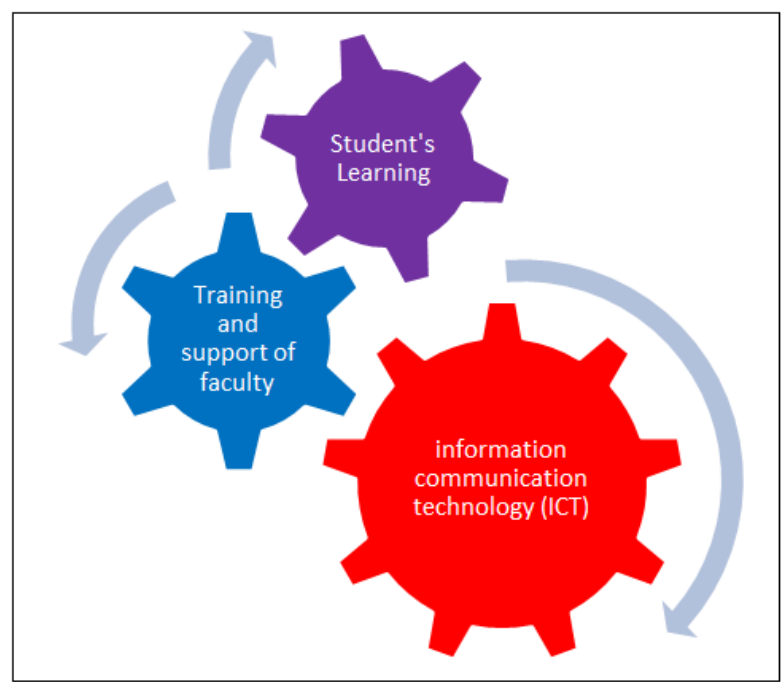

Fig-1: A cycle of e-learning program

\section{Development of the Questionnaire}

They were given self-structured questionnaire, based on frequently asked questions by the facilitators and students during the establishment of the e-learning program. After explaining the purpose of the study and taking informed consent. The questionnaires had a panel of same 11 questions for all the students. All students who cleared the exam in first attempt were included and all students who respond the feedback from within 24 hours and all detainee students were excluded.

\section{RESULTS}

Total students who give the response $133(34.1 \%)$ and the following results were concluded: 
Table-1: \% response of students on Questionnaire

\begin{tabular}{|l|l|l|l|}
\hline S/no & Questions & $\begin{array}{l}\text { Disagree\% } \\
(\mathbf{n = 1 3 3 )}\end{array}$ & $\begin{array}{l}\text { Agree\% } \\
(\mathbf{n = 1 3 3 )}\end{array}$ \\
\hline 1 & Do you have access to internet & $40(30.1 \%)$ & $93(69.9 \%)$ \\
\hline 2 & Do you used internet for education in past & $27(20.5 \%)$ & $105(79.5 \%)$ \\
\hline 3 & Do you find e-learning helpful & $36(27.1 \%)$ & $97(72.9 \%)$ \\
\hline 4 & Do you refer to online educational videos & $65(48.9 \%)$ & $68(51.15)$ \\
\hline 5 & Do you refer online books, study material,wikipedia for education & $74(56.1 \%)$ & $58(43.9 \%)$ \\
\hline 6 & Do you find e-learning better than didactic teaching & $117(89.3 \%)$ & $14(10.7 \%)$ \\
\hline 7 & Do you find power point presentations better than chalk and board method of teaching & $100(75.2 \%)$ & $33(24.8 \%)$ \\
\hline 8 & Do you find online teaching session interesting & $110(83.3 \%)$ & $22(16.7 \%)$ \\
\hline 9 & Do you find online assessment better than written assessment & $105(78.9 \%)$ & $28(21.1 \%)$ \\
\hline 10 & Do you want e-learning to be continue in your college & $104(78.2 \%)$ & $29(21.8 \%)$ \\
\hline 11 & would you like to continue e learning after lock down & $114(86.4 \%)$ & $18(13.6 \%)$ \\
\hline
\end{tabular}

Mostly Students prefer different strategies for learning, a big number of students like Google class room lectures /online 98 (73.8\%), moderate numbers support classroom lectures $21(15.8 \%)$ and small number of students dislike lectures / e-learning 14 (10.5\%). Student's favorite subjects for e learning are Physiology, Biochemistry, Pharmacology, Forensic Medicine and Pathology. Small numbers of students also like Ophthalmology and Gynecology. Students not appreciate to learn surgery, Medicine, Anatomy, ENT and Community medicine through e learning.

\section{DISCUSSION}

Due to covet 19 pandemic situation in Pakistan, the traditional static methods of teaching and learning medical education changed rapidly into the modern and dynamic lines [11]. Now the passive medical student who is to be compelled to education becomes a creative doctor focused on a problem he/ she wants to solve in practice, in other word teachers center learning change into student center learning (selfdirected learning). As we know Pakistan is a under develop country and whole country population not fully facilitated with good, cheep and high speed of internet so the students response regarding the internet facility is only $93(96.6 \%)$ students have a excess of good quality of internet and $40(30.1 \%)$ students have not a good excess of high speed internet. Same results shown in another study which showed that $61.5 \%$ of the students used Internet at their home [12, 13].

The questionnaire based study was conducted to acknowledge the student perception on e-learning in medical education. E-learning has brought radical changes in every sector of education. In this study results shows students are find quite satisfied by elearning because it is helpful Due to the lots of benefits of e-learning, students are more focused and more often acquire knowledge from the internet sources rather than traditional lectures, handouts or text books $[14,15]$.

Majority of the students $(89.3 \%)$ in this study, like to appreciate virtual learning or interactive learning same findings shown by some other studies that the online learning approaches and found that students interacted with the course content more often than they interacted with the instructor, facilitator and fallows [16], but Many studies shows e-learning is more effective, organized, flexible, supportive and well controlled [17, 18]. About 100 (75.2\%) students find power point presentations not better than old traditional method of teaching especially subject Anatomy and only $33(24.8 \%)$ were appreciate the power point presentations then chalk and board method, Jabeen, N \& Ghani, A et al., find the almost same results especially in relation with Anatomy subject [19]. Shaheen et al., study results shows that PPT used is beneficial as supplementary to enhance the efficacy of teaching [20].

The design and execution of online assessments have more impact on student performance either summative or formative, than the method of assessment delivery (online vs face-to-face). Various studies have found no difference in student satisfaction and grades on well-designed online and face-to-face assessments [21], but the results of current study shows $105(78.9 \%)$ students not enjoy online assessments as compare to $28(21.1 \%)$, this result may be due to our traditional summative assessment system which is based on face to face assessment. Most students thought their own growth had improved through use of the traditional assessment system

\section{CONCLUSION}

E-learning is not only a method applied in academic teaching but it is also good method for different courses and trainings, in which the medical professionals may participate during their careers. The lack of ICT competence, useful in e-education upon graduation is a serious problem, as it is difficult for the graduates to obtain such qualifications (experience) outside the college. Students will get better knowledge but not skill and attitude will be deficient.

Correct implementation of e-learning program depends on various factors, like up to date technology and human resources. The most important components include appropriate planning of work. In order to implement and conduct distance education (e learning program) in an efficient way, we need an interdisciplinary team like: experts in ICT competence, 
trained faculty, enthusiastic students and reliable contents.

\section{ACKNOWLEDGEMENTS}

The authors would like to acknowledge all medical students of Pak Red Crescent Medical \& Dental College, Dina Nath

Conflict of Interest: Authors declare no conflict of interest

\section{REFERENCES}

1. Hadadgar, A., Changiz, T., Masiello, I., Dehghani, Z., Mirshahzadeh, N., \& Zary, N. (2016). Applicability of the theory of planned behavior in explaining the general practitioners eLearning use in continuing medical education. BMC medical education, 16(1), 215.

2. Lockdowns not enough to combat coronavirus, WHO warns [Internet]. Available from: https://www.news-

medical.net/news/20200323/Lockdowns-notenough-to-combat-coronavirus-WHO-

warns.aspxhttps://www.news-

medical.net/news/20200319/Coronavirus-can-stayin-the-air-for-hours-and-surfaces-for-days-e28093how-to-disinfect.aspx

3. Ruiz, J. G., Mintzer, M. J., \& Leipzig, R. M. (2006). The impact of e-learning in medical education. Academic medicine, 81(3), 207-212.

4. Gu, X., Wu, B., \& Xu, X. (2015). Design, development, and learning in e-Textbooks: What we learned and where we are going. Journal of Computers in Education, 2(1), 25-41.

5. Juliani, C. M. C. M., Corrente, J. E., \& Dell'Acqua, M. C. Q. (2011). Comparing the teaching-learning process with and without the use of computerized technological resources. CIN: Computers, Informatics, Nursing, 29(6 Topical Collection), TC89-TC97.

6. Masters, K., \& Ellaway, R. (2008). e-Learning in medical education Guide 32 Part 2: Technology, management and design. Medical teacher, 30(5), 474-489.

7. Choules, A. P. (2007). The use of elearning in medical education: a review of the current situation. Postgraduate medical journal, 83(978), 212-216.

8. Kebaetse, M. B., Nkomazana, O., \& Haverkamp, C. (2014). Integrating eLearning to Support Medical Education at the New University of Botswana School of Medicine. Electronic Journal of e-Learning, 12(1), 43-51.

9. e-learning noun - Definition, pictures, pronunciation and usage notes, Oxford Advanced Learner's Dictionary at Oxford Learners Dictionaries.com [Internet]. [cited 2020 May 30]. Available https://www.oxfordlearnersdictionaries.com/defini tion/english/e-learning

10. Masic, I. (2008). E-learning as new method of medical education. Acta informatica medica, 16(2), 102.

11. Kim, S. (2006). The future of e-learning in medical education: current trend and future opportunity. Journal of educational evaluation for health professions, 3 .

12. Özden, M. Y. (2005). Students' perceptions of online assessment: A case study. International Journal of E-Learning \& Distance Education/Revue internationale du e-learning et la formation à distance, 19(2), 77-92.

13. Khan, S. A., Khan, A. A., \& Bhatti, R. (2011). Internet access, use and gratification among university students: a case study of the Islamia University of Bahawalpur, Pakistan. Chinese Librarianship: an International Electronic Journal, 32, 1-14.

14. Fischer, M. R. G. (2003). E-Learning in medical education. Med Klin, 98(10):594-607.

15. Ruiz, J., Mintzer, M., \& Leipzig, R. (2006). O impacto do e - learning na educação médica. Med Acadêmica; 81(3):207-212. Available from: https://journals.lww.com/academicmedicine/Abstr act/2006/03000/The_Impact_of_E_Learning_in_ Medical_Education.2.aspx

16. Camelia, D., \& Plăstoi, I. B. (2019). Social \& Behavioural Sciences Edu World 2018 The 8 Th International Conference Sports Education And Its Impact On The Health And. Eur Proc Soc Behav Sci EpSBS.

17. Newton, N., \& Stewart, A. (1994). Personality Development in Adulthood. Wiley-Blackwell Handb Adulthood ... ... [Internet]. Available from:

http://onlinelibrary.wiley.com/doi/10.1002/978111 8392966.ch11/summary

18. Bjekic, D., Krneta, R., \& Milosevic, D. (2010). Teacher education from e-learner to e-teacher: Master curriculum. Turkish Online Journal of Educational Technology-TOJET, 9(1), 202-212.

19. Jabeen, N., \& Ghani, A. (2015). Comparison of the traditional chalk and board lecture system versus power point presentation as a teaching technique for teaching gross anatomy to the first professional medical students. J Evol Med Dent Sci, 4(11), 1811-17.

20. Shahdad-Shaheen, A. K. M. (2017). Power Point or Chalk and Board - Students View Towards Method of Teaching Anatomy. Int J Anat Res. 5(1):3510-3512.

21. Weleschuk, A. (2019). Online Assessment in Higher Education. Taylor Institute for Teaching and Learning Guide Series. Calgary, AB Taylor Inst Teach Learn Univ Calgary. Available from: http://taylorinstitute.ucalgary.ca/resources/guides. 